\title{
From International Law to International Conflicts of Law: The Fragmentation of Legitimacy
}

Harlan G. Cohen

University of Georgia, hcohen@uga.edu

p bepress SSRN

\section{Repository Citation}

Harlan G. Cohen, From International Law to International Conflicts of Law: The Fragmentation of Legitimacy, 104 Am. Soc'y Int'I L. Proc. 49 (2010),

Available at: https://digitalcommons.law.uga.edu/fac_artchop/929

This Article is brought to you for free and open access by the Faculty Scholarship at Digital Commons @ University of Georgia School of Law. It has been accepted for inclusion in Scholarly Works by an authorized administrator of Digital Commons @ University of Georgia School of Law. Please share how you have benefited from this access For more information, please contact tstriepe@uga.edu. 


\title{
Georgia
}

\section{UNIVERSITY OF GEORGIA SCHOOL OF LAW}

\author{
RESEARCH PAPER SERIES
}

Paper No. 10-13

June 2010

From International Law to International Conflicts of Law: The Fragmentation of Legitimacy

\author{
HARLAN GRANT COHEN \\ Assistant Professor \\ University of Georgia School of Law \\ hcohen@uga.edu
}

Forthcoming in

American Society of International Law Proceedings,

Vol. 104 (forthcoming 2010)

This paper can be downloaded without charge from the Social Science Research Network electronic library at http:// ssrn.com/ abstract=1632873 


\title{
From International Law to International Conflicts of Law: The Fragmentation of Legitimacy
}

\author{
Harlan Grant Cohen*
}

\section{From Fragmenting Doctrine to Fragmenting Communities}

Oftentimes, the potential fragmentation of international law is treated as a doctrinal or technical problem. It is assumed that those interpreting the rules within human rights, or international investment law, or international criminal law are working from the same set of sources, and disagree only on issues of interpretation and application. Under this view, if we could find a means of choosing between interpretations, perhaps a rule of treaty interpretation ${ }^{1}$ or even an appeals court of international law, or if we could devise doctrinal tweaks that could reconcile these interpretations, for example, a new interpretation of the opinio juris requirement for customary international law, these fragmentation problems would disappear. This view essentially treats conflicts between human rights and trade the way we would treat conflicts between contracts or torts in domestic law-both are part of the same legal system, and as such, the system can provide doctrines to reconcile or choose between them.

In this presentation, which is based on a longer paper, I challenge both this conventional view of fragmentation and the basic notion that there is a single international law community with a single doctrine of sources. I argue that despite our constant invocation of Article 38 of the Statute of the International Court of Justice and the traditional doctrine of sources, it is not at all clear that the legal actors in these different subject areas actually agree on the legitimate sources of international law. On the contrary, what the problem of fragmentation reveals is that a single international law community is actually being replaced by separate, overlapping legal communities with significantly different views on law and legitimacy. These communities disagree on the very "who" and "how" of international lawmaking, and as such, debates between these communities - between human rights and international humanitarian law or between trade law and environmental law - often represent debates over legitimacy rather than conflicts over interpretation.

Reframing the problem as a debate over legitimate process helps us better understand our options for resolving it. To the extent these debates are debates about legitimacy, they will not be resolved with doctrinal fixes. Instead, they must essentially be viewed as conflicts of law. Resolving those debates will require finding ways to mediate between the demands of different legal communities.

\footnotetext{
* Assistant Professor of Law, University of Georgia School of Law

${ }^{1}$ See, e.g., U.N. Int'l Law Comm'n, Report of the Study Group on the Fragmentation of International Law: Difficulties Arising from the Diversification and Expansion of International Law, U.N. Doc. A/CN.4/L.682 (Apr. 13, 2006) (finalized by Martti Koskenniemi).
} 


\section{Getting to the Source(s) of the Problem}

This paper is not the first to suggest that fragmentation may be the result of fragmenting normative-legal communities. Legal pluralists like Gunther Teubner ${ }^{2}$ and Paul Berman ${ }^{3}$ have made similar suggestions. This paper gets to this conclusion, however, in a novel way. It does so by tracing the problem to its source, taking a fresh look at the doctrine of sources itself.

In an earlier article, ${ }^{4}$ I argued that the time has come to rethink the list of sources in Article 38 of the ICJ statute, i.e., treaties, custom, and general principles. I argued that if we draw upon what we have learned about how law works over the last century since the doctrine of sources was first codified-lessons from H.L.A. Hart's socio-legal theory, from law and society scholarship, from international compliance theory-we start to move away from a doctrine of sources based on the form a particular rule takes (whether it is a treaty or a custom) to a doctrine of sources based on the processes through which rules come to be treated as law. Drawing particularly on compliance and social norms theories, I argue that rules come to be treated as international law in one of two ways. First, some rules will be directly internalized by international actors. Although some of these rules will be substantive - states may internalize a prohibition on genocide or slavery - others which we might term "legitimacy rules," will focus on process-they may explain what counts as a binding agreement, what evidence is needed to legitimate a customary practice as law, or dictate when such an agreement must be followed. Essentially these internalized legitimacy rules provide standards against which purported rules will be judged. They also help define the legal community. The legal community can be thought of as that group which shares a certain set of "legitimacy rules." A second category of rules treated as international law, "legitimated rules," builds on this first one. Rules in this category are treated as law because they satisfy the internalized legitimacy rules. Thus, as an example, some human rights may be treated as international law because those rights have simply been internalized, while others may be treated as international law because they're embodied in a document that meets internalized standards of legitimacy.

Looking at sources this way allows us to take a closer look at fragmentation and see what really is going on. When looked at through the lens of this revised doctrine of sources, at least some disputes over international law appear to be disputes about legitimacy rules. In a number of areas, the legal community appears to be changing, sometimes to include actors others than states. As the community has transformed, so too has its internalized understandings of what constitutes legitimate rulemaking.

\footnotetext{
${ }^{2}$ See generally Andreas Fischer-Lescano \& Gunther Teubner, Regime-Collisions: The Vain Search for Legal Unity in the Fragmentation of Global Law, 5 MiCH. J. INT'L L. 999 (2004); See also generally Benedict Kingsbury, International Law as Inter-Public Law, in NOMOS XLIX: MORAL UNIVERSALISM AND PLURALISM at 176 (Henry R. Richardson and Melissa S. Williams eds., 2009).

${ }^{3}$ See, e.g., Paul Schiff Berman, Global Legal Pluralism, 80 S. CAL. L. ReV. 1155, 1169 (2007). Berman mostly looks at conflicts between international law and state law, regional law, or transnational regulatory regimes, but at least implies that his view would apply to intra-international law conflicts as well.

${ }^{4}$ Harlan Grant Cohen, Finding International Law: Rethinking the Doctrine of Sources, 93 IowA L. REv. 65 (2007).
} 
International human rights law, Global Administrative Law, and the law applied in tribunal-centered areas of law provide three examples of communities that appear to be developing in this way. In each of these areas of law, rules have developed that cannot easily be squared with traditional doctrine. In human rights law, we have the emergence of "instant" custom, the notion that customary international law can be proven based on what states say, traditional evidence of opinio juris, even in the absence of state practice, or possibly in the presence of state practice to the contrary. Similarly, within human rights law, the Human Rights Committee of the International Covenant on Civil and Political Rights has claimed not only the authority to determine whether a reservation is in line with treaty's objects and purpose and valid, but also that where invalid, a state will be bound by the whole treaty including the provision it attempted to reserve. Both are significant departures from traditional doctrine and its traditional justifications in state consent. Scholars of Global Administrative Law have observed that various transnational regulatory regimes - some public, some private, some legal, some non-legal-have begun to adopt similar rules regarding transparency, participation, reason-giving, and means-end proportionality, rules that cannot easily be traced to formal sources of international law. And, in tribunal-intensive areas of international law like international criminal law and international investment arbitration, the use of precedent has become widespread, despite suggestions in Article 38 to the contrary.

Although each of these has been treated as a doctrinal problem, each seems better explained by shifting international law communities and shifting notions of legitimacy. In human rights law, it has long been recognized that individuals now play some role as members of the legal community. It makes sense that as that legal community has developed to include individuals, expert bodies, and advocacy groups as well as states, legitimacy rules based solely on state consent would lose some force and need to be replaced. In the case of human rights, it appears that a new legitimacy rule has emerged, one that says that state promises matter and that states cannot vitiate those promises merely through state action to the contrary. Similarly, the emerging rules of Global Administrative Law seem best explained as responses to the legitimacy rules internalized by overlapping communities of regulators and stakeholders. Finally, the use of precedent seems like a response by a tribunal-centered legal community-one made up of judges, lawyers, victims, and violators - to a need for neutral, predictable rules in areas where traditional state practice may be underdeveloped or unreliable.

\section{From Conflicts of Norms to Conflicts of Law to Conflicts of Legitimacy}

Assuming that this account is persuasive, it suggests some lessons about the problem of fragmentation. To the extent these disputes are about legitimate rulemaking - the "who" and "how" of international law-we are not going to be able stitch things back together with doctrinal fixes. Instead, we are going to need to treat these conflicts as ones between different systems of law and search for rules that can mediate between the concerns of these different communities. 
Working out these rules is a particularly vexing problem, something that will undoubtedly fuel future projects. Analogies to conflicts between subject areas within a single legal regime and analogies to conflicts between the laws of different states both seem inappropriate to these disputes between overlapping legal communities. Four broad approaches seem to suggest themselves, each with their own benefits and drawbacks. One would be a conservative/common denominator approach. Such an approach would recognize that Article 38 no longer describes international law but nonetheless use it as a conflicts rule: All disputes between different communities will have to be funneled through traditional doctrine. Such an approach recognizes the continued role of states in all these communities, controls the pace of legal change, and provides a focal point communities can use to influence each other. A second, more radical approach would favor the rule of the most inclusive community, the one in which the most stakeholders could have their voices heard. Such an approach seems normatively appealing, but requires difficult, perhaps impossible analyses of contestable terms like "more inclusive" or "more legitimate." A third managerial or pluralist approach, would try to preserve community autonomy through margins of appreciation, subsidiarity, or complementarity. The problem with such an approach is that figuring out how those doctrines should apply is notoriously difficult. Finally, a competition approach would suggest that the best conflict rule is no conflicts rule, that these disputes can and should spur longer-term political and moral debates, and that competition may allow better results to emerge. Such an approach depends, however, on valuing the future over the present and on a confidence in the eventual outcome of these disputes.

\section{Conclusion}

Fragmentation is more than just a technical challenge for international scholars; it is a challenge to our most deeply held assumptions about the nature of international law. Moving forward will require us to confront the fragmentation of community, sources, and legitimacy fueling that challenge. 